\title{
TEMPLOMOK, TEMETKEZÉSEK ÉS EGY ÜVEGHUTA: KÖZÉPKORI ÉS KORA ÚJKORI ÁSATÁSOK A 15 ÉVES ÁSATÁRS KFT. FELTÁRÁSAI KÖZÜL
}

\section{GaLLINA Zsolt - GuLYás GyöNGYI}

Magyar Régészet 9. évf. (2020), 1. szám, pp. 35-44. doi: https://doi.org/10.36245/mr.2020.1.2

A Magyar Régészet online magazin elözö számában három olyan őskori lelöhelyet mutattunk be, melyek feltárására az elmúlt két évben cégünk meghatározó munkáinak keretei között került sor. Jelen tanulmányban ugyancsak az elmúlt néhány év három jelentös közép-és kora újkori lelöhelyén végzett munkájáról számolunk be. Ezek azért is állnak különösen közel hozzánk, mert mindhárom feltárás tervásatás volt, melyet részben a Nemzeti Kulturális Alap által támogatott pályázatainknak köszönhetöen tudtunk megvalósítani. A Garábon végzett feltárás anyagi fedezetét pedig egyedülálló módon a terület tulajdonosa biztositotta.

\section{KÖZÉPKORI TEMPLOM ÉS TEMETŐ GARÁBON}

A Nógrád megyei Garáb (Grabensia, Gravia) középkori temploma és kolostor épületei a 18. században újjáéledő falu építkezéseinek eshettek áldozatul. A település ma is álló, Szent Alajos katolikus templomának falában és több házba beépítve a mai napig megfigyelhetőek a faragott, feltehetően innen származó kövek. A lelőhelyen először 1987-ben végzett Bodnár Katalin és Maicher Tamás kutatóárkos feltárást, melynek célja az egykori monostor helyének pontos meghatározása volt. Ekkor sikerült feltárni egy egyenes szentélyzáródású templom és a feltételezett kolostoregyüttes bizonytalan részleteit, valószínüleg annak kettős kerítő falát, továbbá észlelték a templom körüli temető 14 sírját is (F. BODNÁR, 1988, 35-36).

A 2000-es évek eleje óta a terület új tulajdonosa, Juhász György, nagy érdeklődést mutatott a középkori Garáb történelme iránt, így pártfogásába vette az egykori templom és kolostoregyüttes megkutatását is. Távlati célja a feltárt templom falainak lehetséges magasságig történő rekonstrukciója és bemutatása. Ennek köszönhetően 2018-ban megkezdődtek a tervásatások, melyek célja a középkori templom teljes feltárása, illetve a 2017-ben készített geofizikai felmérésen jelentkező falszakaszok ásatása volt. A munkálatok során megkutattuk a késő középkori település kis részét, továbbá a több száz síros templom körüli temető bizonyos részleteit is (1. kép). Ennek köszönhetően le is határolható a temető ÉNy-i széle.

2018-2019-ben közel 500 jelenséget, mintegy 400 sírt/vázmaradványt, illetve középkori és kora újkori településobjektumot dokumentáltunk. Az ásatások legjelentősebb eredményeit a közel görögkereszt alakú, centrális szerkezetü, 11-12. században épített, 14,7 m hosszú és 12 m szélességü, K-Ny-i irányú templom feltárása hozta (2. kép). A Ny-i hajótraktus csak mintegy 1,4 m-rel hosszabb

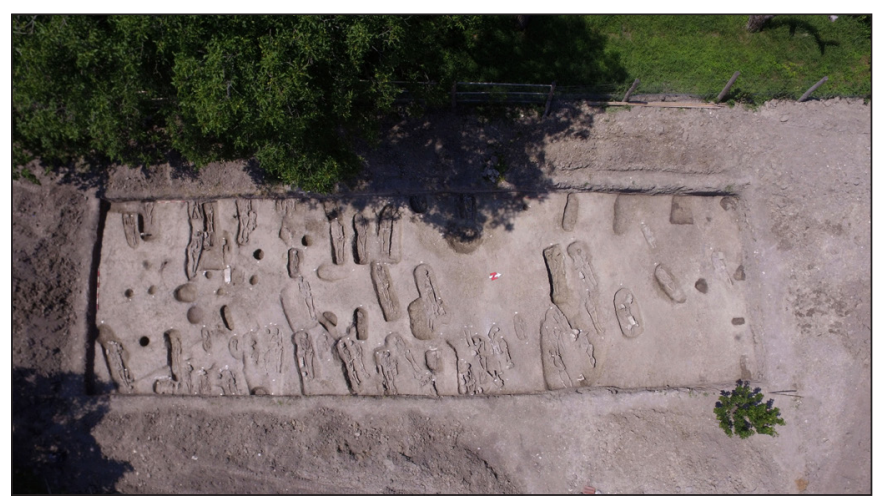

1. kép. Garáb, templom körüli temető részlete légi felvételen (Készitette: Kurucz Máté és Czukor Péter)

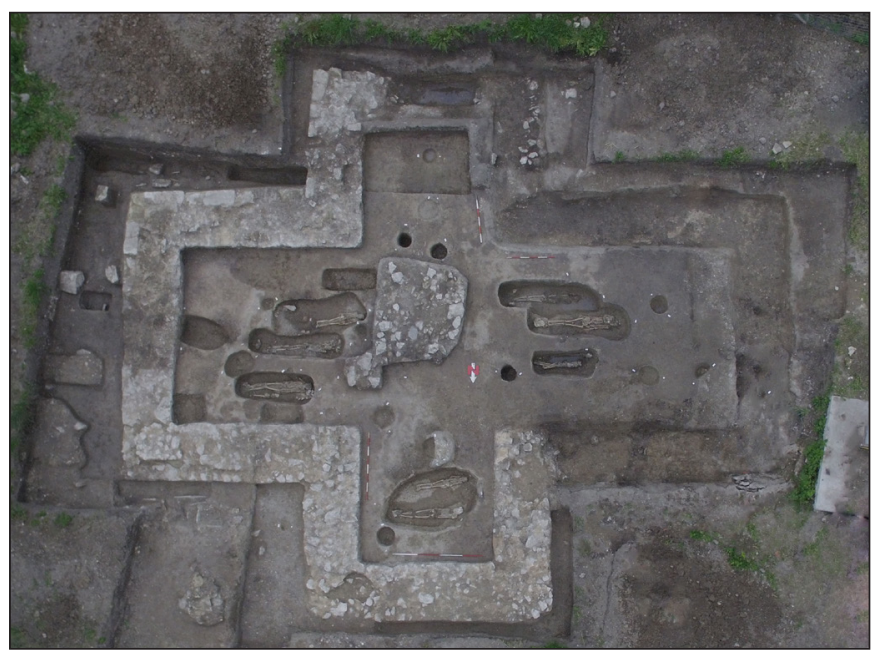

2. kép. Garáb, görögkereszt alakú templom légi felvételen (Készitette: Kurucz Máté) 
Gallina Zsolt - Gulyás Gyöngyi • Templomok, temetkezések és egy üveghuta: Középkori és kora újkori ásatások...

a téglalap alakú K-i traktusnál, ennél valamivel zömökebb a két kereszthajó, melyek teljesen tükörképei egymásnak, szélességük 390-420 cm, hosszuk 530-540 cm. A templom falazatát a teljes szentélyben, az É-i kereszthajóban és a D-i kereszthajó DNy-i részén lehetett megfogni. Máshol csak az alapozó árok maradványait bontottuk ki, melyböl később kitermelték az építőanyagot. Egyértelmüen megfigyelhető az ún. öntött falas építési technika, azaz a fal széléhez hosszanti irányba helyezett, téglalap alakú, 30-35 cm-es kváderkövek közé törmelékes-habarcsos anyagot töltöttek. A belső törmelékes falmag többnyire magasabban maradt meg, mert a külső kvádereket bányászták ki később elsősorban. A templom falszélessége 125 és $135 \mathrm{~cm}$ között változott, míg a kiszedett alapozó árok 120-140 cm szélességü. A templom belső és külső részén, a mélyítés során elértük az egykori járószintet. A templom belső részén, továbbá a falszakaszok külső oldalának közelében számos kerekded alakú cölöphelyet bontottunk ki. Ezek betöltésének különbözősége alapján úgy gondoljuk, hogy azokat nem egyszerre ásták ki, és nagy valószínüség szerint a templom esetleges építési periódusaival vagy javítási munkálataival függhetnek össze. A templom belső részében elszórtan terrazzo padló maradványát is rögzíteni tudtuk.

A templom közvetlen környezetében a gyepszinttől 30-35 cm-re, az elplanírozott köves-törmelékes rétegben, egészen az altalajig (1-2 m-es mélységig) több száz temetkezést tártunk fel. A törmelékes réteg eltávolítása után több sírfedlapot is találtunk a templomtól É-ra, melyek másodlagos helyen, de közel egy szinten és egymás közelében feküdtek. A vázak megközelítöleg Ny-K-i irányúak, az elhunytakat általában háton fekve, nyújtott testhelyzetben temették el. A karokat a test mellé fektették vagy könyökben behajlították és/vagy a has részre vagy pedig a medencékre helyezték, egy-két esetben az egyik kart az állhoz hajlították vissza. Több sírban is találtunk koporsóra utaló nyomokat: famaradványt, a sír jelentkezési szintjén vagy alján szürkésbarna foltot, illetve koporsószögeket. Ugyancsak több Árpád-kori sír alján vagy az elhunytak csontjain faszénmaradványt találtunk. A sírokban megfigyelt égésnyomok a 12 . században jelennek meg, feltehetően déli hatásra. Valószínüleg nem pogány szokás, Rosta Szabolcs szíves szóbeli közlése szerint elképzelhető, hogy a tisztítótüz szimbólumaként értelmezhetjük. Néhány esetben a test halotti lepelbe csavarása is feltételezhető a karok szoros test melletti helyzete alapján. Mellékletet szinte alig leltünk. Két sírban a szájba helyezett halotti obulust, valamint egyszerü, nyitott, nagyméretü karika ékszereket, S-végü hajkarikákat, egyszerü pántgyürüket, egy esetben üveggyöngyöt és egy esetben fejes ezüstgyürüt bontottunk ki. Szórványként egy vas övcsat is felszínre került (3. kép).

Közel 30 váznál figyeltünk meg eltéréseket, melyeket alapvetően két csoportra lehet osztani: az eredendően rendellenesen eltemetettek és az utólagosan manipulált sírok. Az előző csoportba zsugorított helyzetü és hason fekvő elhunytak (egy hasra fektetett váz a templombelsőben is volt), az utóbbiba pedig azok tartoznak, melyeket a temetés utáni években bolygattak meg: megfordították mindkét combcsontjukat vagy mindkét lábukat, többnyire szétdúlták koponyájukat, elmozdították felsőtestüket (4. kép). E tevékenység mindig a koporsón belül folyt, így a sírhantok még létezhettek akkor. A combcsontok és a lábak kiforgatásához viszont

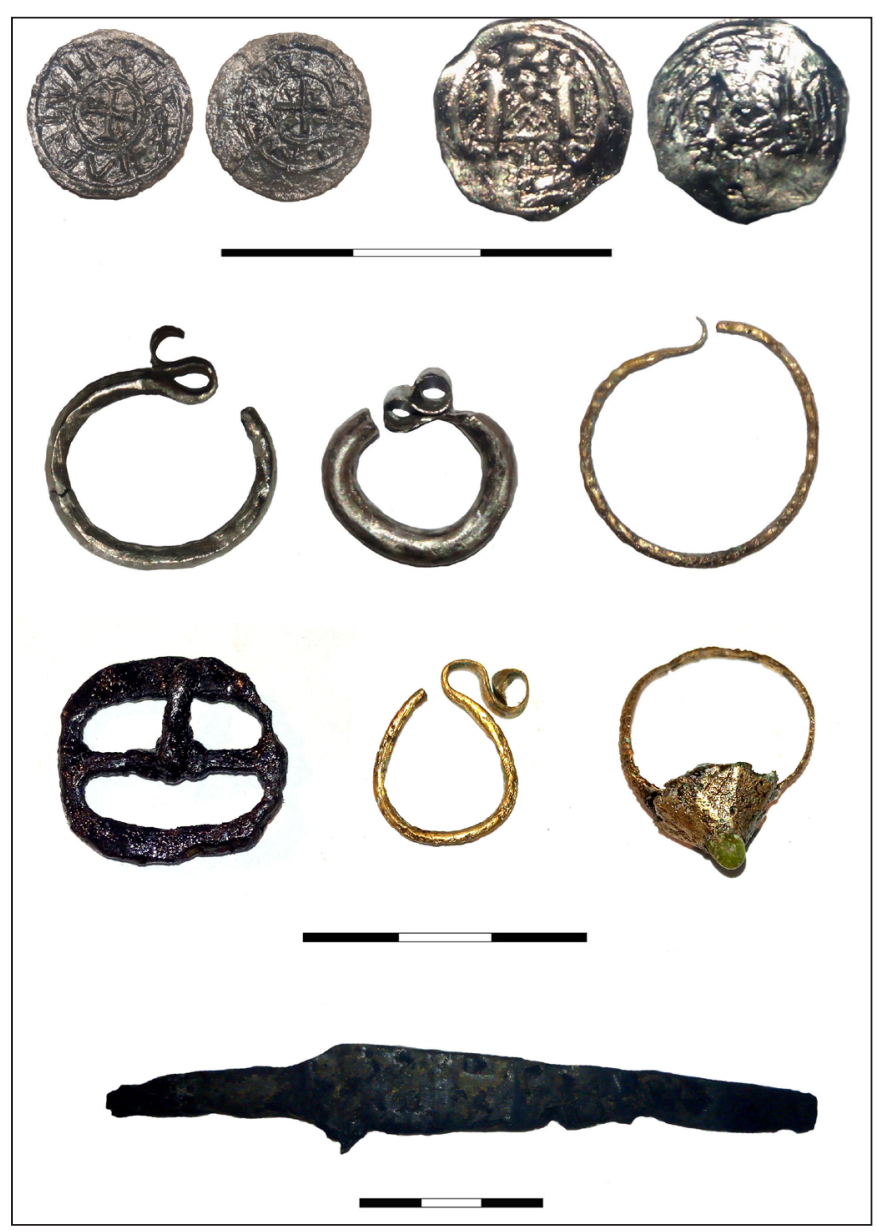

3. kép. Garáb, fémleletek a lelöhelyröl (Fotó: Gulyás Gyöngyi és Barta Gábor) 
Gallina Zsolt - Gulyás Gyöngyi • Templomok, temetkezések és egy üveghuta: Középkori és kora újkori ásatások...

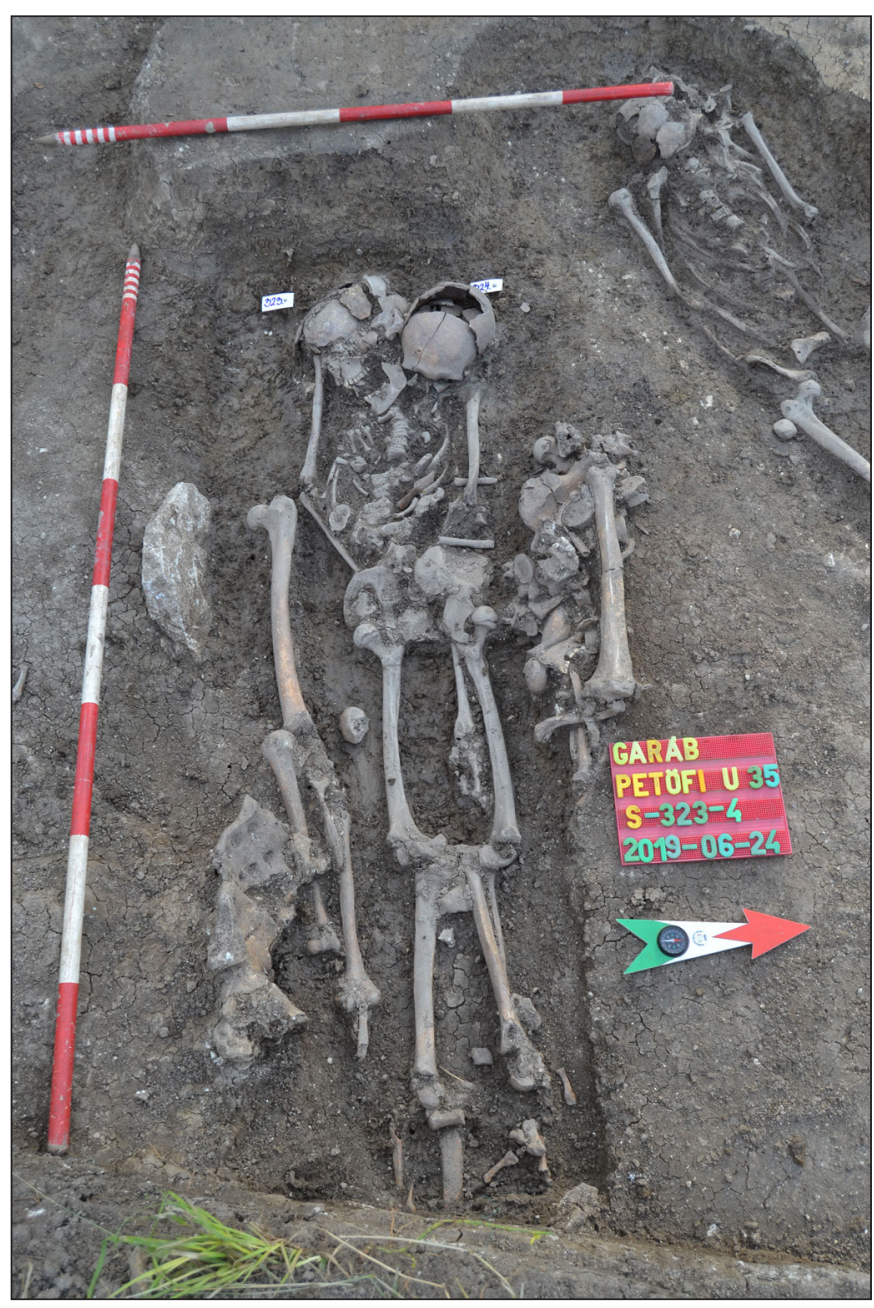

4. kép. Garáb, utólagosan felforgatott temetkezés (Fotó: Gulyás Gyöngyi) már a testnek porladnia kellett, mert vágásnak nincs nyoma. Ez alapján a temetés után jó néhány évvel, de maximum 3-4 évtizeddel történhettek a bolygatások. A jelenség okait nehéz meghatározni, leginkább csak hipotéziseket lehet megfogalmazni. Nagy valószínúség szerint a visszajáró halottól való félelem sajátos helyi variánsa vagy egy új népesség érkezéséhez köthetö(?) nagyon durva gyalázás-sorozat sejthető e tettek hátterében. Ezen sírok közül kettőben találtunk korhatározó leletet, halotti obolusként Kálmán király (1095-1116) szájba helyezett ezüst denárját.

Ez alapján már a premontrei kolostor létesítése (1179) előtt volt Garábon egy korábbi temető és egy templom is. Nagy kérdés, hogy e templom lett-e a premontrei rend egyháza a későbbiekben. Az alaprajz teljesen idegen, és tudunk egy másik temetőről a mai templom közelében, alig 200 m-re, talán itt kereshetjük a premontrei rend egyházát. Távlati terveink között szerepel a korai templom és a premontrei kolostor teljes feltárása és rekonstrukciója.

1436-ban a konvent kihalt, birtokait az ipolysági rendház kapta meg, majd 1688-ban a besztercebányai jezsuitáké lett, akik felépítették a ma is álló templom elődjét. Az egykori premontrei épületegyüttes 1797-ben még álló falait a falu újjáépítésekor a helyi lakosság széthordta (F. BoDNÁR, 1988, 35-36).

\section{HONFOGLALÁS KORI SÍR, KÖZÉPKORI FALU, TEMETŐ ÉS TEMPLOMOK TÁZLÁR-TEMPLOMHEGYEN}

Tázláron (Bács-Kiskun megye) 2003 óta folynak próba-, megelőző és tervásatások. 2019-ig több mint $7000 \mathrm{~m}^{2}$-t kutattunk meg a 40 hektáros lelöhelyböl. A feltárt 1044 jelenség között több mint 580 Árpád-kori és középkori sír/vázrészlet, két templom, egy hármas árok és pár száz középkori településobjektum volt.

Tázlár az Alföld szívében a Homokhátságon helyezkedik el Kiskunhalas-Kiskunmajsa-Soltvadkert háromszögében. A terület a környék egyik legismertebb régészeti lelőhelye, melyet a nép nyelve, pontosan emlékezvén a régi időkre, Templomhegy néven őrzött meg. A lelőhely sajnos folyamatosan pusztult az elmúlt évtizedekben az intenzív földmüvelés, kincskeresés és földelhordás során.

A lelöhelyen a honfoglalás korából - a 10. század közepe tájáról - származik az egyik legjelentősebb emlék, egy előkelő nő temetkezése (a sírról részletesebben ld. GuLYÁs, GALLINA \& TÜRK, 2019, 115-121). A Ny-ÉNy-K-DK-i tájolású, téglalap alaprajzú sírgödörben nyújtott, hátán fekvő, 50 év feletti, europomongolid jellegü (turanid) nő jó megtartású csontváza feküdt. ${ }^{1}$ A váz kissé É-i irányba „préselődött” a sírgödör falához, amely így eredetileg talán padmalyos kialakítású lehetett. Lábvégei előtt és felett lóbőr nélküli részleges lovastemetkezést tártunk fel (5. kép). A Maros torkolat Ny-i oldalán általános temetkezési szokás gyökereit a honfoglalók még keletről hozták magukkal.

A sírban összesen $94 \mathrm{db}$ melléklet volt (6. kép). A két ezüst karikaékszer mellett a mell és a has tájékán egy-egy apró bronz fülesgomb zárta a ruházatot, annak alját, a csukló környékét pedig keskeny, vékony

\footnotetext{
A vázat Marcsik Antónia vizsgálta meg.
} 

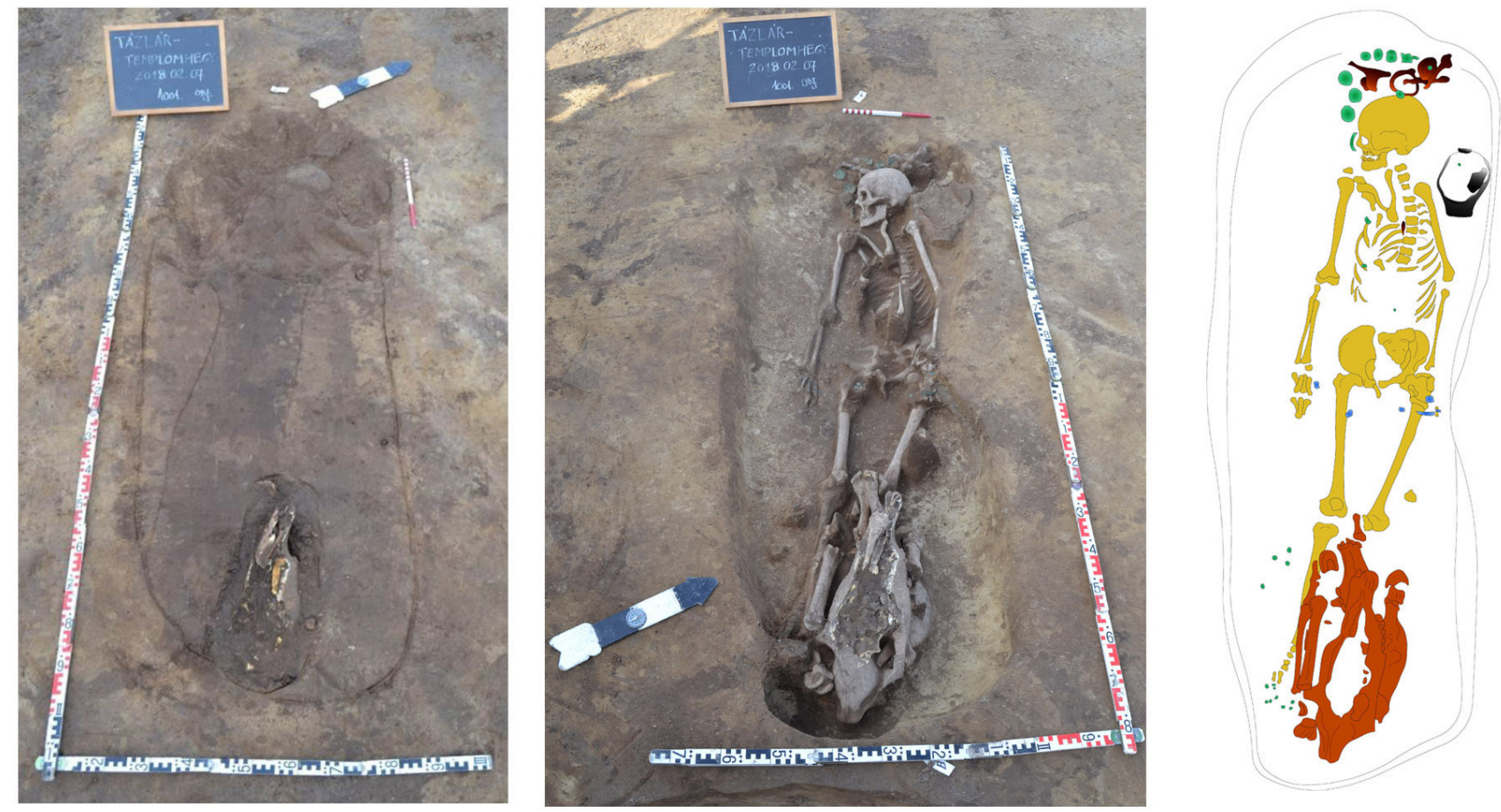

5. kép. Tázlár-Templomhegy, honfoglaló sír folt-, felszinfotója és felszinrajza

(Fotó: Gulyás Gyöngyi, rajz: Gallina Zsolt, térinformatika: Archeoline Kft.)

ezüstlemezek díszítették. Az elhunyt a bal kezén ezüst pántkarperecet, ujján ezüst pántgyürüt figyeltünk meg, míg mellkasán egy vasár feküdt. Lábbelijének felső részét több mint 60 db apró, félgömbfejü ezüstverettel varrták ki. A nő feje alá helyezték a nyerget és a lószerszámzatot, köztük a kisméretü, aszimmetrikus, körte alakú vaskengyeleket, valamint az oldalpálcás zablát. Továbbá a szíjazatot is, amelyet többféle méretü rozettás, ónozott bronz verettel (összesen $12 \mathrm{db}$ ) és egy szintén rozettás mintájú nagyszíjvéggel díszítettek. A szíjazatot összehajtva fektették a sírba. A lószerszámzat általában a lócsontokon vagy azok közelében kerül elö, ritkán fektetik azokat az elhunyt feje alá vagy mellé.

A rozettás lószerszámveretek a korszak régészeti hagyatékának egy igen jellegzetes csoportját alkotják. A Duna-Tisza közére kifejezetten jellemző a tárgytípus, de az egyik legáltalánosabban elterjedt lelet a teljes 10. századi Kárpát-medencében. A rozettás veretek azonban a Kárpátoktól K-re is elöfordulnak, ahol az utóbbi években megduplázódott a számuk: ma már 13 leletről van adatunk KeletEurópától egészen Délnyugat-Szibériáig (GuLYÁs, GALLINA \& TÜRK, 2019, 115).

A sír a kiskunhalasi pusztában nem egyedülálló, ugyanis Balotapusztán és Kiskunhalas-Dénes Mar-

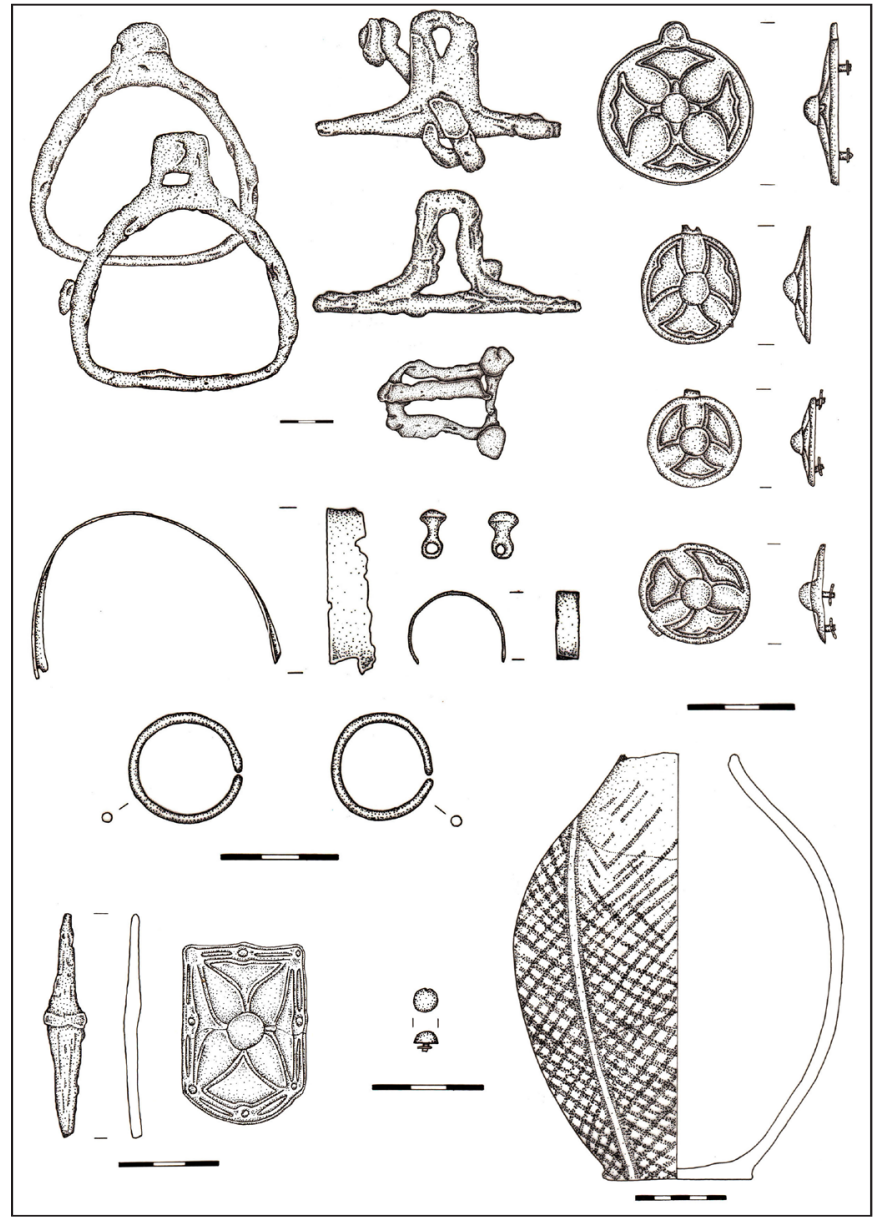

6. kép. Tázlár-Templomhegy, honfoglaló sír mellékletei (Restaurálta és rajzolta: Barta Gábor) 
Gallina Zsolt - Gulyás Gyöngyi • Templomok, temetkezések és egy üveghuta: Középkori és kora újkori ásatások...

cell utcában is találtak egy-egy, a tázlárihoz hasonló lovas, rozettás lószerszámdíszes női sírt. Az ilyen sírok hazánk egész területén előfordulnak, de az így eltemetettek egy zárt, a hagyományaihoz jól kivehetően ragaszkodó (pántkarperec és -gyürü, fülesgombok, veretes csizma, alig van ruhadísz), feltehetően rangos társadalmi csoport tagjai lehettek (RÉvÉsz, 2001, 58-64). Elterjedésük talán összefüggésben áll az egykori nemzetségek letelepedésével, rendre 10-15 km-re kerülnek elö egymástól (RÉvÉsz, 2001, 68, 42. kép; LANGER, 2017, 2-3. kép).

A tázlári temetkezés legérdekesebb lelete a bal felkar mellett fekvő, oldalára dőlt, nyújtott, tojásdad testü korsó, a külső oldalán fehér alapon vörös rácsmintával festve. A lelet a honfoglalás kori régészeti hagyatékban egyelőre teljesen egyedülálló. Az edény legközelebbi párhuzamát az Első Bolgár Cárság 10. századi fővárosából, Preszlav lelőhelyről ismerjük, ahol a preszlavi festett kerámiaáru csoportba sorolható. A mai Bulgária területéről származó importleletek a Kárpát-medence 10-11. századi régészeti hagyatéka balkáni kapcsolatrendszerének megítélésében kiemelkedő szerepet játszhatnak. A tázlári kerámialelet új fejezetet nyithat a 10. századi Kárpát-medence és Bulgária - eddig csak főként a fémleletek stíluskritikai szempontú elemzésein alapuló - kapcsolatrendszerének vizsgálatában (GULYÁs, GALLINA \& TÜRK, 2019, 116).

Jelenlegi tudásunk szerint a 11. századtól fogható meg temetkezéseiben az a köznépi csoport, aki itt megtelepszik és temetkezik, majd a 11-12. század fordulóján valamikor templomot emelt. A méretesebbek közé tartozó, félköríves szentélyü, ÉK-DNy-i tájolású falusi templom $(13,5 \times 9$ m) köré létesült a már kereszténynyé vált Ârpád-kori népesség temetője. A falu, a népesség életének és a temető használatának a tatárjárás vetett véget (részletesebben ld. Gallina \& GulYÁs, 2018a, 44-49). A késő Árpád-kori faluban több speciális, cölöpszerkezetes - bélést vagy oldalszelement tartó - épületet, bennük speciális, patkó alakú, szürkére égett, cementálódott anyagú kemencét leltünk. Az említett kemencék vagy inkább újraizzító tüzhelyek mellett számos objektumban voltak salakok és mellfalazat darabok, melyek alapján feltételezhető, hogy ipari tevékenységet (vaskovácsolást, esetleg rézolvasztást) végeztek e mühelyekben. A külterületi laposabb részen, nagyméretü, négyszögletes alakú árokrendszerek, intenzív állattartásra utaló karámok kerültek elö.

A falutól K-re találjuk az Árpád-kori temetőt, mely körbeveszi a templomot. A sírok többsége nem a megszokott Ny-K-i irányú volt, hanem DNy-ÉK, azaz a fej volt DNy-D-i irányban, a templomhoz igazodva. A két tájolási csoport (Ny-K, DNy-ÉK) közül a DNy-ÉK-iek rendre későbbiek voltak és a korábbiak egyfajta soros rendjét is megfigyelhetjük. Feltehetően a korai köznépi temető fejlődött templom körülivé (úgynevezett gellértegyházi típus), ennek bizonyítása azonban még a jövő feladata.

Több sírnál figyeltünk meg oldalfülkét, ún. padmalyt, melyet a sírgödör bal, azaz a K-i oldalára ástak. Az elhunytakat nyújtott helyzetben, háton fekve, több esetben halotti lepelbe tekerve, ritkán koporsóban temették el. A kartartás általánosnak mondható: mindkét kar a test mellett nyugodott, de néha előfordult az is, hogy az egyik kart a test előtt behajlították. A megszokott fektetések mellett néhány rendellenes temetkezést - főként idős egyéneknél - és kettős temetkezést (nő férfivel, anya újszülött gyermekével) is találtunk. A nehéz életet élő és kétkezi munkát végző népesség csontjain számos patológiás elváltozás (kar-, láb- bordatörések, erős izomtapadások, reumás betegségek nyoma) figyelhető meg. ${ }^{2}$ Az Árpád-kori sírokban kevés melléklet volt: bronz és ezüst, egyszerü, egymásra hajtott végü- és „S”, sima vagy bordázott végü hajkarikák, egyszerü bronz és ezüst huzalgyürük, illetve néhány ezüstobulus a 12-13. századból. A legkésőbbi, tatárjárás előtti sírok közül az egyikből Bernhard karintiai herceg 1220-as évekbeli verete került elő.

A településhez tartozó templomot hármas körárok-rendszerrel vették körbe, melynek elsődleges feladata nem a temető lehatárolása, hanem a templomkörzet védelme volt. A külső, közel $110 \mathrm{~m}$-es területet felölelő árok markáns, még a mai lepusztult felszínen mérhető 2,5 m-es szélessége és 1,5 m-es mélysége is tekintélyt parancsoló. A külső árokból számos vasszerszám, balta, kapa, sarló, két sarkantyú, ún. juhnyíró olló, övcsat, kés, ajtóvasalás, abroncsos favödör pántja, számos középkori tégla, ép malomkő, nagy menynyiségü, nagyobb és égett kőtöredék, köztük sok faragott kváderkő került elő, ami a templom eröszakos pusztulására utalt. Az árkok alsó részén megfigyelhető égett, faszenes, feltehetően a tatárjárás időszakából

Az embercsontokat Marcsik Antónia és Bernert Zsolt vizsgálta meg. A Bernert Zsolt által vizsgált maradványok közül több egyén koponyáján is jelképes trepanáció volt. 
Gallina Zsolt - Gulyás Gyöngyi • Templomok, temetkezések és egy üveghuta: Középkori és kora újkori ásatások...

származó pusztulási rétegben leégett épület deszkafalai is az árokba dőltek. Mivel a külső árok minden Árpád-kori sírnál későbbi volt, ezért valószínüleg azt közvetlenül a tatárjárás elött áshatták ki, majd a bekövetkező pusztulás nyomai kezdték megtölteni.

A középső árokban találtuk egy hason fekvő felnőtt csontvázát, a halott az árokba eshetett, vagy szertartás nélkül lökhették oda harci cselekmények kapcsán. Ugyanebben a középső árokban egy ehhez hasonló helyzetü férfi hátrakötözött kezű vázát is feltártuk. Az elhunyt a tatárdúlás utáni évtizedekben került az árokba: félhettek töle még holtában is, hiszen fordítva tájolva, hasra fektetve, összekötözve, fejéhez rontást elhárító sarlókat, lábához kést téve, az Árpád-kori templom köveivel kirakva helyezték el (7. kép).

A zürzavaros időszakban az itt élök igyekeztek elrejteni az értékeiket. Szintén a középső árokból került elő egy szabad tüzön fözésre használt bográcsból és nyolc különböző méretű fazékból/bögréből álló leletegyüttes. Talán élelmet rejthettek el bennük.

A hármas árokrendszer külső tagját biztosan, a középsőt pedig valószínüleg a tatárjárás zürzavaros időszakában áshatták meg, de hasztalan, mert a település elpusztult...

Hasonló többszörös (kettes-hármas), védelmi funkcióval bíró árkokat figyeltek meg a közeli Szankon, Kiskunfélegyházán, Kunfehértón, Szabadszálláson, Dunavecsén, Csengelén, Tótkomlóson és Orosháza-Szentetornyán is (RostA, 2018, 190, 6. kép).

A tatárjárást követő évtizedekben vagy a búvóhelyükröl visszatérö magyarok vagy az itt megtelepülö korai kun csoportok beköltöztek a templom közelébe, az erődített külső árkon belülre. S itt építették fel meglepő fejlettségü, bélelt falú, nagy méretü, összetett szerkezetü veremházaikat (8. kép). Az egyik ház kemencéjének tủzfogóját például vélhetően a templom tégláiból építették meg. A kunok - akik nagyobb számban a 13. század második felében, a 14. század elején telepedtek meg itt - a 15. század első felében a romos, de még részben álló falú templom helyére újat építettek. A késő középkori templom tájolása teljesen megegyezett az Árpád-koriéval, falaik szinte tökéletesen illeszkedtek egymáshoz. Az Árpád-kori templom külső falsíkja a későbbi templom belső falsíkját képezte. Szentélye némileg változott, szélesebb és félköríves záródású lett (9. kép).

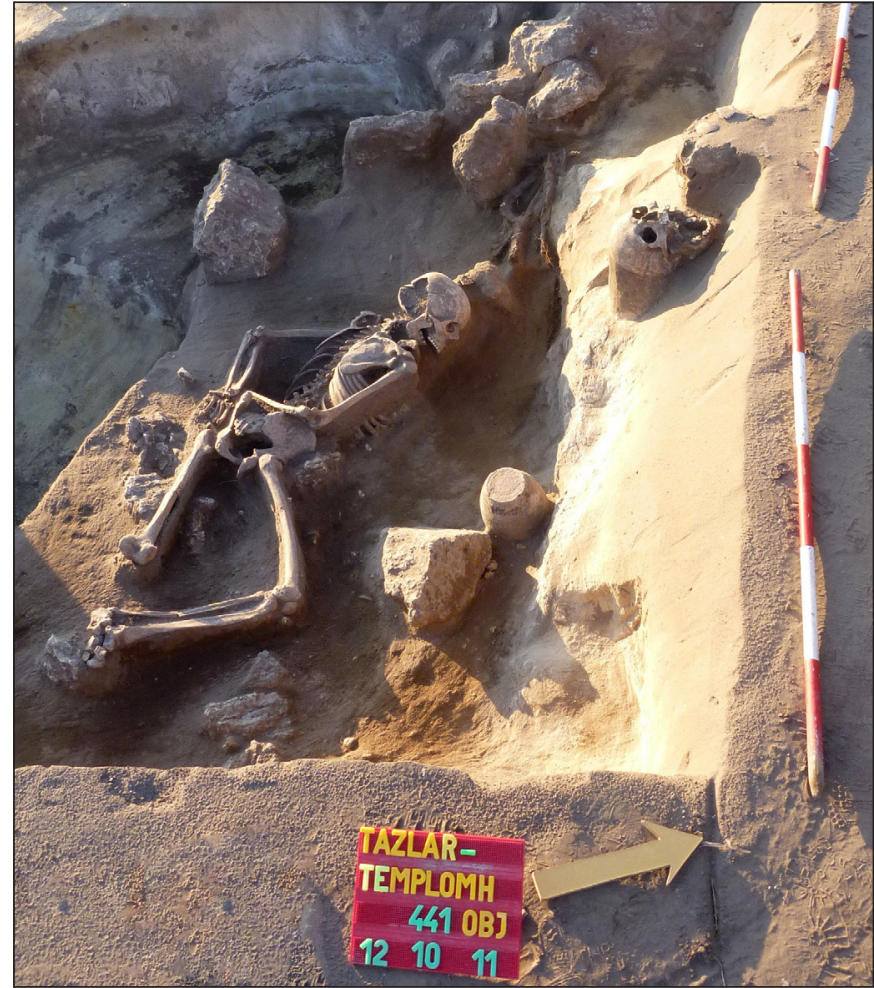

7. kép. Tázlár-Templomhegy, összekötözött kezü elhunyt a középsö keritö árokban (Fotó: Gulyás Gyöngyi)

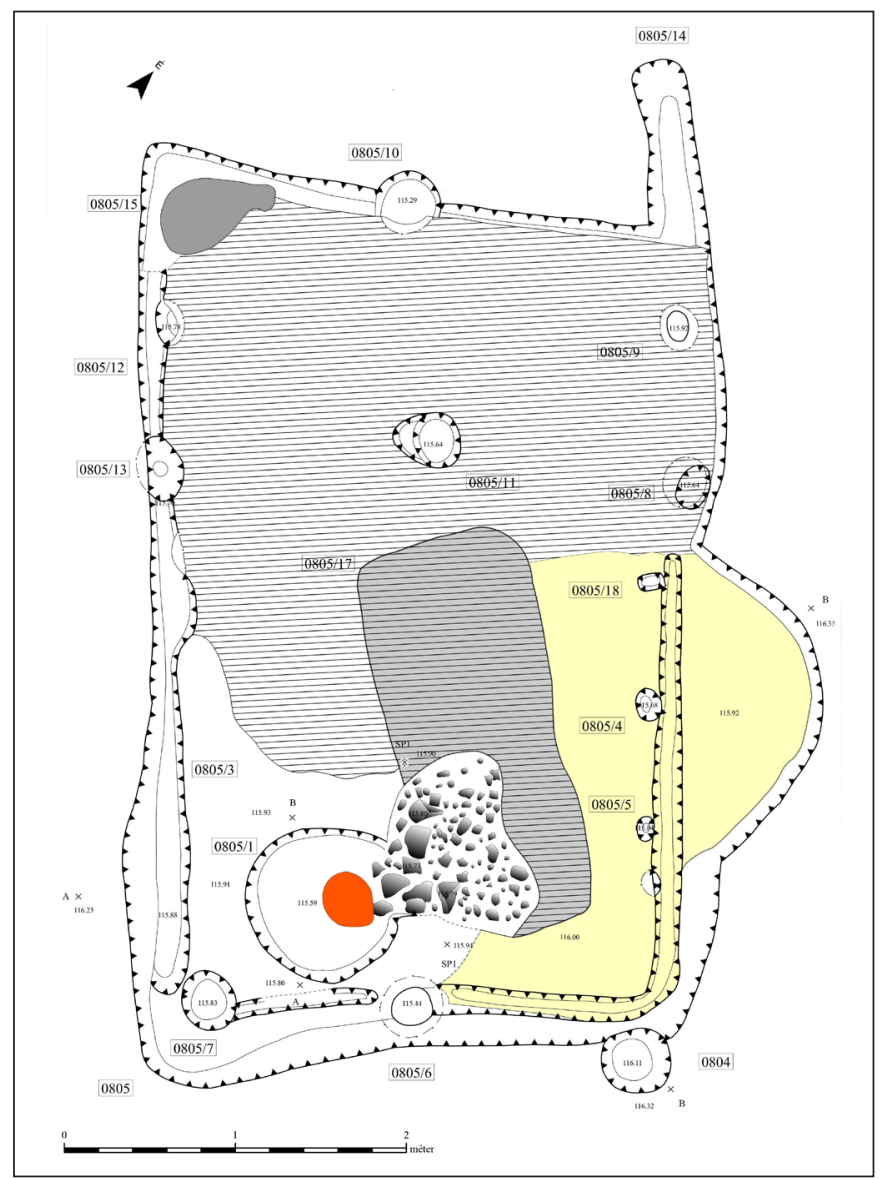

8. kép. Tázlár-Templomhegy, 13-14. századi épület felszínrajza (Rajz: Gulyás Gyöngyi, térinformatika: Archeoline Kft.) 
Gallina Zsolt - Gulyás Gyöngyi • Templomok, temetkezések és egy üveghuta: Középkori és kora újkori ásatások...

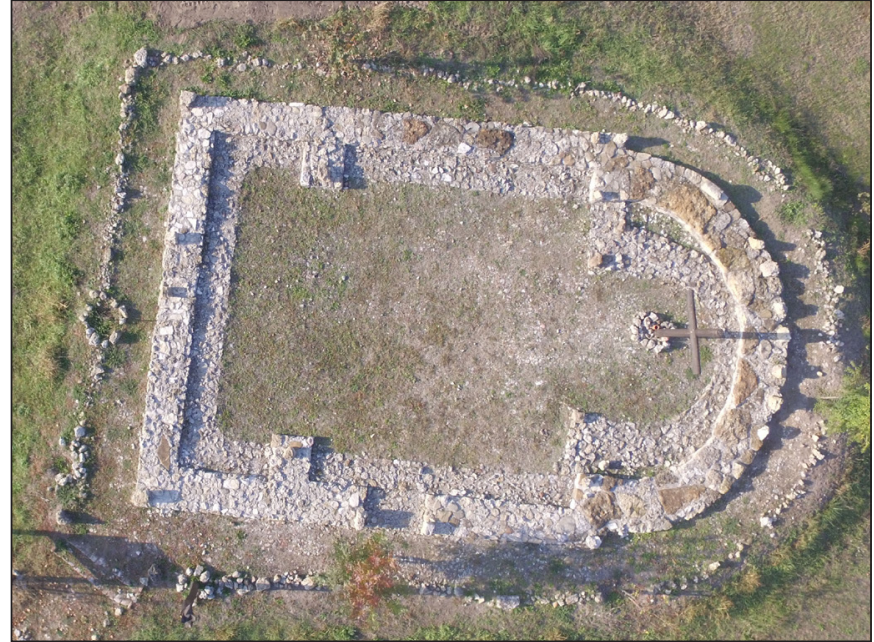

9. kép. Tázlár-Templomhegy, középkori templomok rekonstrukciója légi felvételen (Készítette: Kurucz Máté)

A 11-16. század között használt temető késő középkori sírjai általában DNy-ÉK-i tájolásúak. Általános a szegelt vagy pántokkal megerősített deszkakoporsó használata és az elhunytak kartartása is változott, színesebb kép bontakozik ki, jóval több a medencére, melltájékra hajlított kar. Ezek a megállapítások elsősorban a templom belsejében eltemetettekre vonatkoznak. A sír kiégetése, a tisztító szertartás során visszamaradt faszén maradvány mintegy 30 Árpád-kori és késő középkori sírban volt megfigyelhetö.

E kései periódus sajátos jelensége, hogy a korábbi Árpád-kori sírokat ún. osszáriumba gyüjtötték és ásták el. A késő középkori sírokban is kevés mellékletet találtunk: ún. párizsi kapcsokat, bronz és vas övcsatokat, kéttagú ruhakapcsokat, fejes gyürüket kettőskereszt és madárábrázolással, ruhavereteket, préselt korong alakú lemezeket, pártavereteket. Egykét kun sír jellegzetes lelete volt még a gyöngyös tarsoly, vaskéssel és ezüst tarsolyzáró verettel, illetve a felhúzott lemezgömb fülbevaló díszes övverettel.

Néhány sírban éles vastárgy (nyílhegy, sarló) is volt, mely pogány szokásmaradványként, baj- vagy rontáselhárító szerepként értelmezhető.

A feltárt területen 2014-től kezdve régészeti emlékparkot alakítottunk ki. Rekonstruáltuk a két templom falmaradványait és az árokrendszer már feltárt részeit. A munkálatokat jelenleg is folytatjuk. Igyekszünk látható emlékké tenni a múltat és öseink erőfeszítéseit, a mai generációknak okulásul.

\section{KORA ÚJKORI ÜVEGHUTA PUSZTABÁNYÁN}

Az üvegművesség egykoron virágzó manufakturális iparág volt hazánkban, ami különösen a török kiüzését követően, a 17. század végétől lendült fel. Ekkor terjedt el szélesebb társadalmi körben az ablaküveg és a mindennapi használtra szánt ún. öblösüveg. A Kelet-Mecsekben a 17. század legvégétől a 19. század elejéig négy mühelyben készítettek üveget, melyek közül az utolsó, a Pusztabányán álló 1784 és 1805 között müködött (bővebben ld.: LANG, 2008). Az iparrégészeti lelöhelyen a korábbi évtizedekben Kárpáti Gábor vezetésével, Jegenyés János üvegművész és ifj. Lang Ádám történész közreműködésével már folytak feltárások, és készültek üvegkemence rekonstrukciók. A korábbi kutatók nyomdokain haladva - 2016 és 2018 között - nyílt lehetőségünk arra, hogy a teljes üvegcsürt feltárjuk, ezáltal rekonstruálni tudjuk annak müködését (GaLlina \& GuLYÁs, 2018b, 64-68). A feltárásról és a 2019ben végzett rekonstrukciós munkálatokról a Pazirik Kft. készített kisfilmet és 3D rekonstrukciókat Gallina Zsolt útmutatásával (Pazirik Kft., 2019).

A pusztabányai üvegmüves épület egyedülállóan jó állapotban maradt meg hazai és nyugat-európai viszonylatban is, hála annak, hogy utolsó lakói elhagyták és nem bontották el. Az építmény teljes hoszszúsága $37-38 \mathrm{~m}$, szélessége $11-15 \mathrm{~m}$, a nagy méretek ellenére még sincs belső alátámasztásnak nyoma (10. kép).

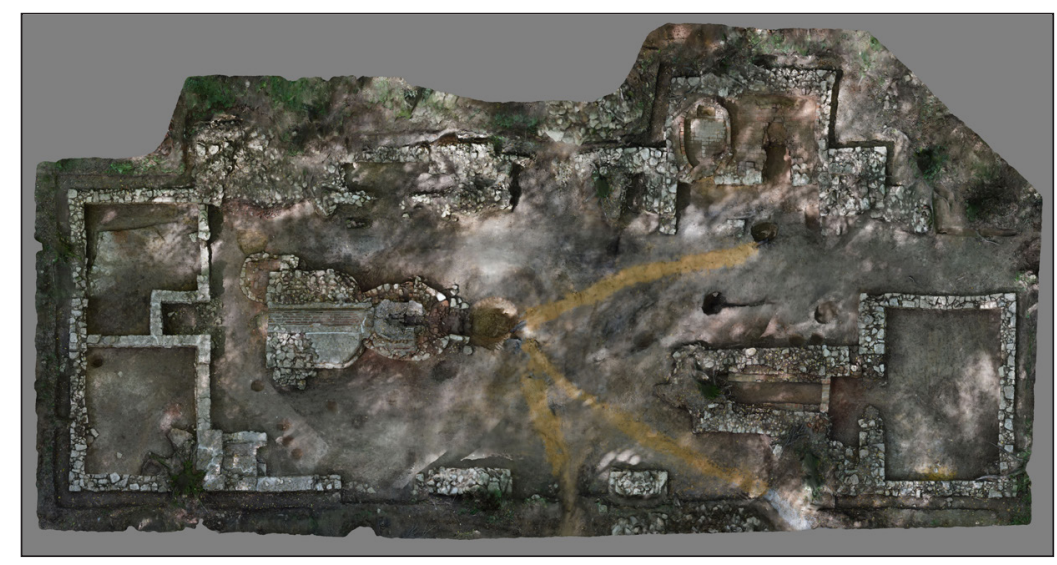

10. kép. Hosszúhetény-Pusztabánya, üvegcsür légi felvételen (Készitette: Pazirik Kft.) 
Gallina Zsolt - Gulyás Gyöngyi • Templomok, temetkezések és egy üveghuta: Középkori és kora újkori ásatások...

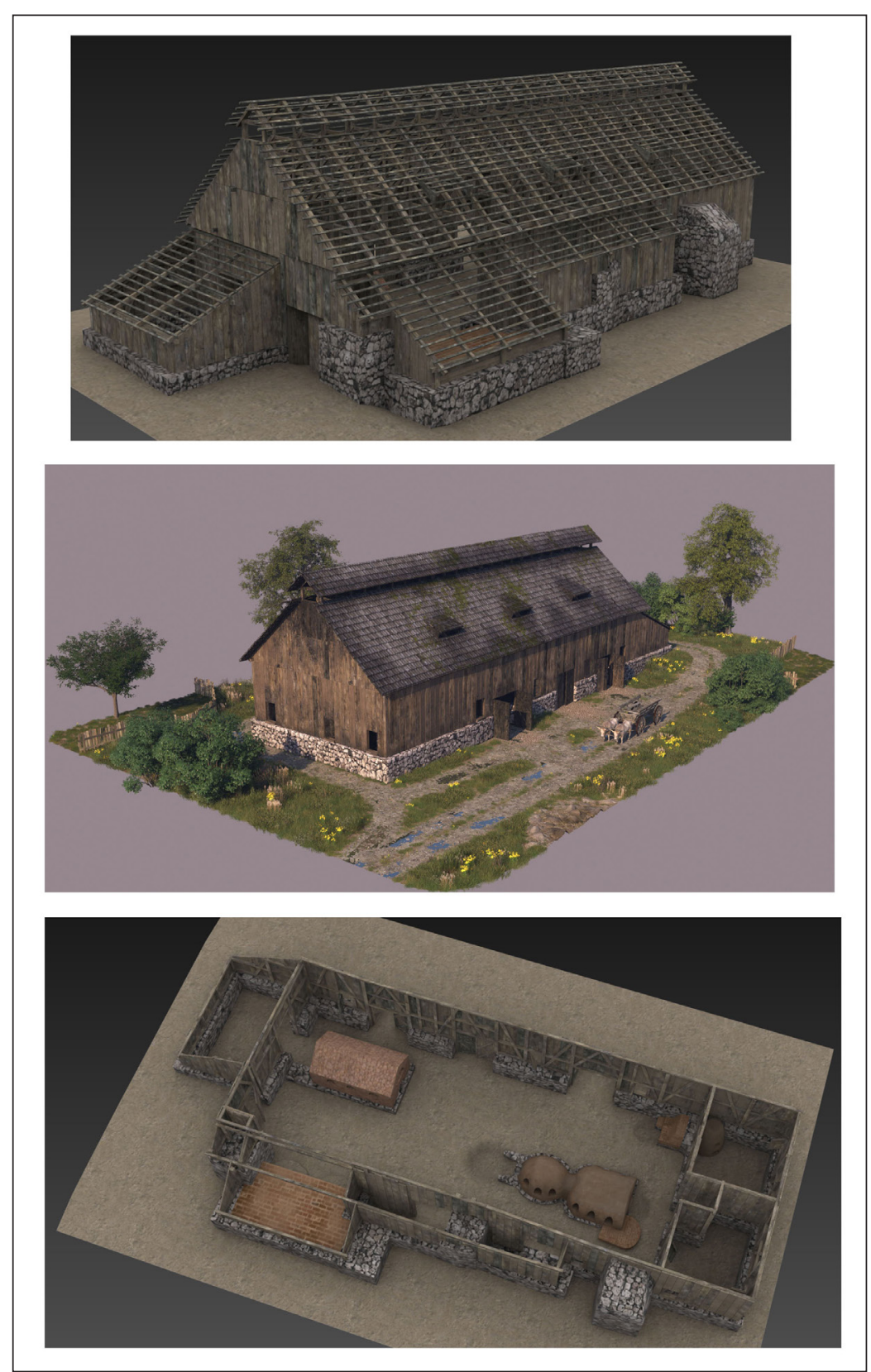

11. kép. Hosszúhetény-Pusztabánya, üvegcsür $3 D$ rekonstrukciójaaz épület szerkezete, a rekonstruált épület és a belső elosztása (Készitette: Pazirik Kft.)
Az ún. üvegcsürben több munkafolyamatot is végeztek: itt szárították a tüzifát, olvasztották a kvarchomokot, majd hamuzsír és mész hozzáadásával állították elő az üvegolvadékot. Itt történt az üvegfújás, a késztermékek kialakítása és szárítása is. Itt tárolták a fúvóformákat, a hütés során használt agyagtálcákat, a különféle eszközöket és talán a késztermékeket is.

Az üvegcsür központi részén helyezkedett el a jó állapotban megmaradt ún. kettős (olvasztó és temperáló) kemence. Körülötte megtaláltuk a keményre letaposott, korabeli padlószintet is.

A kettőskemencétől É-ra egy közel 5 m hosszú, téglalap alakú, kívül kőből, belül téglából épített, feltehetően faszárító kemence feküdt. Az üvegcsür Ny-i oldalán egy, az épület síkjából erősen kiugró, kívül kőből, belül téglából álló, téglapadozatú-, kettős kürtős kemenceegyüttest is feltártunk. Feltehetően ezek szolgálhattak a síküveg gyártására, kalcinálásra, színező anyagok előállítására. Az összes kemence körül számos kisebb gödör, kiszolgáló egység, leletkoncentrálódás, égett felület, a korabeli munka színtere mutatkozott, jelezve az egyes munkafázisok kifinomult részleteit.

A nagyméretű épület É-i és D-i végén helyiségek kerültek elö. Az É-i végén levő helyiség készáru- vagy faraktár lehetett. A DNy-i helyiséget feltehetően vegyszer-, méreg- és mészraktárnak használhatták. A DK-i helyiség, melyet szemes kályhával füthettek télen, az olvasztár lakhelye lehetett, aki itt tárolta az üvegfúváshoz használt eszközöket (fúvóforma töredékek), szerszámait (üvegvágó olló) és az ún. agyagtévőket.

Az alig több mint két évtizedig müködő üvegcsürt a domboldal felöl támpillérekkel erősítették meg, és több jel is utal arra, hogy legalább egyszer átépítették.

A K-i falat három helyen egy-egy, közel 3 m hosszúságú, az alján lapos kövekkel kirakott kapu tagolta. Az üvegcsür É-i oldalán is volt egy bejárata, melynek alja erősen lejtett az épület felé (11. kép).

A feltárás során hatalmas mennyiségü üveglelet került elő, melyek tábla- és zöld színü parasztüvegek, ún. erdei üvegek töredékei voltak. Néhány olyan unikális töredéket is találtunk, mely alapján tudjuk, hogy a huta nemcsak „,tömegcikkeket”, hanem megrendelésre egyedi, drága üvegeket is előállított. Ilyen két domború liliomdíszes, áttetsző üvegpohár és egy kék festékkel színezett peremű kancsó töredéke. Emellett elökerültek az üvegedények gyártásához szükséges kő- és agyageszközök is (agyag fúvóforma, kőtégely, hütésre használt kerámia lapok/tálcák darabjai, ún. agyagtévők, üvegcsövek) (12. kép). A gyártáshoz kap- 
Gallina Zsolt - Gulyás Gyöngyi • Templomok, temetkezések és egy üveghuta: Középkori és kora újkori ásatások...

csolódó leletek mellett az itt dolgozókhoz köthető személyes tárgyak is felszínre kerültek, pl.: fémfedeles pipa, ezüst övcsat, vaskések, gyürü, vasolló, reszelö, mázas és máztalan táltöredékek és számos, 1761 és 1800 közé keltezhető érme.

A huta életéről annyit tudunk, hogy nem vált igazi faluvá, az itt dolgozó délnémet és cseh-morva vidékekről érkező üvegmüvesek jórészt Kisújbányáról jártak ki, ahol a korábbi üveghuta volt. A környezö, felszíni nyomok és LIDAR felvételek tanulsága szerint azonban még számos épületet sejthetünk a csür körül (hutamester háza, fürészmalom, békasótörő malom, üvegraktár, elökészítő mühelyek stb.). Egy biztos, hogy Pusztabánya (Vitriaria) volt az utolsó kelet-mecseki üveghuta, gyorsan lakatlanná vált. Az üvegcsür felhagyása után vándorkovácsok és/vagy cigányok húzták meg magukat a még álló falak között. A huta vagy a település kiürülése vagy az ideiglenesen itt tartózkodók távozása után leégett. Ezt követően gyorsan benőtte az erdő a romokat, de ez is örizte meg.

A feltárás után elkezdtük a romok állagmegóvását és tervezzük rekonstrukcióját, hiszen az épület európai szinten is egyedülálló módon maradt meg és vált értelmezhetővé, bemutathatóvá. $\mathrm{S}$ reméljük, hogy valóban felébred több évszázados álmából és újra a Mecsek gyöngyszemévé válhat, mint Baranya vármegye egykoron legnagyobb ipari létesítménye.

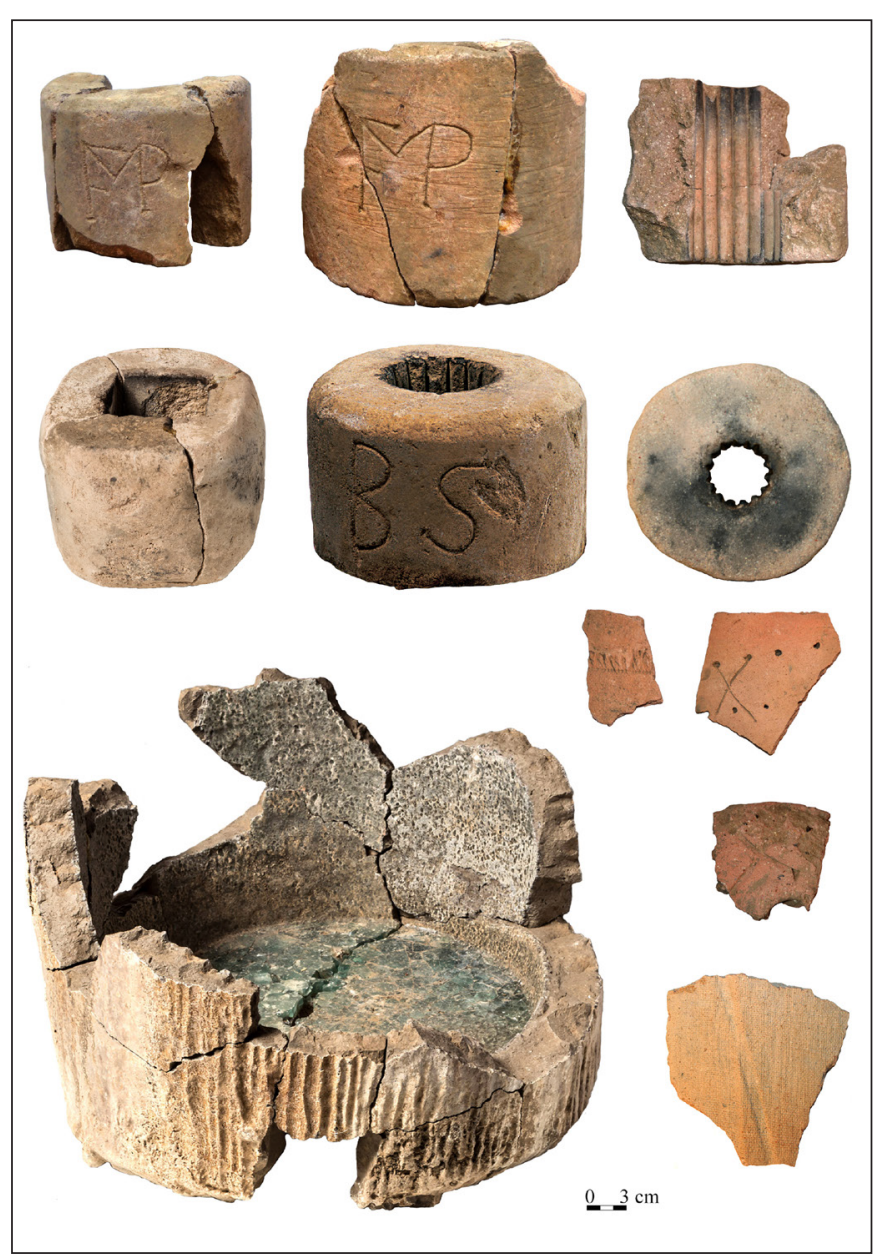

12. kép. Hosszúhetény-Pusztabánya, leletek az üvegcsürböl (Restaurálta: Móricz Róbert, Fotó: Móricz Róbert és Gulyás Gyöngyi)

BiBLIOGRÁFIA

F. Bodnár, K. (1988.) Kolostor a kiskertben. Múzeumi Mozaikok 1988 (2), 35-36.

Gallina, Zs., Gulyás, Gy. (2018a). Homokba temetett falvak és templomok. A tatárjárás korának emlékei a Kiskunságban. Határtalan Régészet 3 (1), 44-49.

Gallina, Zs., Gulyás, Gy. (2018b). „Pusztabánya hol régenten övegbánya volt, egyes maradványa még látható”. Az utolsó mecseki üveghuta története. Határtalan Régészet 3 (4), 64-68.

Gulyás, Gy., Gallina, Zs. \& Türk, A. (2019). Újabb régészeti adatok a Duna-Tisza köze honfoglalás kori településtörténetéhez és a 10. századi bolgár-magyar kapcsolatok kérdéséhez egy tázlári sír kapcsán. In Sudár B., Türk A. (szerk.), „Hadak útján”. A népvándorláskor fiatal kutatóinak XXIX. konferenciája. Absztraktkötet (pp. 115-121). Budapest: PPKE, Martin Opitz.

Lang, A. (2008). Üveghuták a Kelet-Mecsekben. Pécs.

Langer, D. (2017). A honfoglalás kori rozettás lószerszámveretek keleti kapcsolatrendszere. OTDK dolgozat. Pécs. 
Gallina Zsolt - Gulyás Gyöngyi • Templomok, temetkezések és egy üveghuta: Középkori és kora újkori ásatások...

Pazirik Kft.(2019). Az utolsómecseki üveghuta története. https://www.youtube.com/watch?v=1I3vss6SuIM. Letöltés: 2019.11.27.

Révész, L. (2001). Aranyszántás Balotán. Gazdag honfoglalás kori női sírok Kiskunhalas környékén. Budapest-Kiskunhalas: Magyar Nemzeti Múzeum.

Rosta, Sz. (2018). Egy új lehetőség kapujában - tatárjáráskori védművek a Kiskunságban. In Mérai D. (ed.), Genius loci. Laszlovszky 60. (pp. 186-192). Budapest: Archaeolingua. 